\title{
Canadian guidelines for the management of acute exacerbations of chronic bronchitis: Executive summary
}

\author{
Meyer S Balter MD FRCPC ${ }^{1}$, Jacques La Forge MD FRCPC CSPQ ${ }^{2}$, Donald E Low MD FRCPC 1,3 , \\ Lionel Mandell MD FRCPC ${ }^{4}$, Ronald F Grossman MD FRCPC FACP ${ }^{1}$ and the Chronic Bronchitis Working Group \\ on behalf of the Canadian Thoracic Society and the Canadian Infectious Disease Society
}

cute exacerbations of chronic bronchitis (AECB) account
for over 1.5 million physician visits annually in Canada
and are a cause of significant morbidity and mortality. Canadian
guidelines for the management of chronic bronchitis were pub-
lished in 1994 (1). The present document is an update of our
original guidelines, and is a joint effort by the Canadian
Thoracic Society and the Canadian Infectious Disease Society.

\section{METHODS}

Early in 1999, a needs assessment survey was sent, along with the 1994 guidelines, to representative family physicians from across Canada. The purpose behind this was to obtain insight into the major challenges these physicians faced in diagnosing and managing AECB. A committee was established comprised of members from both the Canadian Thoracic Society and the Canadian Infectious Disease Society, as well as two family physicians with strong interests in continuing medical education. Relevant articles published between 1966 and July 1, 2002 were retrieved from MEDLINE using the index terms 'chronic obstructive pulmonary disease' (COPD), 'chronic bronchitis' combined with 'acute exacerbations', as well as specific terms relating to various interventions such as 'steroids', 'bronchodilators', 'anticholinergics', 'antibiotics' and 'mucolytics'. Articles published before 1966 were retrieved from the reference lists of more recently published papers. The Cochrane Controlled Trials Register was also searched until the end of the year 2001. Abstracts from the American Thoracic Society, American College of Chest Physicians, European Respiratory Society and International Conference on Antimicrobial Agents in Chemotherapy meetings from 1999 to 2002 were reviewed.

Treatment recommendations were graded on the strength of evidence, similar to the grading used for the Canadian guidelines for the initial management of community-acquired pneumonia (2). Well-conducted, randomized, controlled trials constitute strong or level I evidence; well-designed, controlled trials without randomization, including cohort and case-control studies, constitute level II or fair evidence; and expert opinion, case studies, and before and after studies constitute level III or weak evidence. In the present guidelines, these ratings appear as Roman numerals in parentheses after each recommendation.

\section{DEFINITION}

COPD is now the fifth leading cause of death in Canada, and its prevalence is increasing (3). Most definitions consider COPD to be a disease state characterized by air flow limitation that is not fully reversible $(4,5)$. The air flow limitation is usually progressive and associated with an abnormal inflammatory response of the lungs to inhaled particles or gases. COPD is an umbrella term that includes the entities of chronic bronchitis and emphysema when associated with air flow limitation. Ordinarily, asthma, cystic fibrosis, bronchiectasis and bronchiolitis obliterans are excluded from this definition.

Chronic bronchitis is defined as expectoration of sputum on most days during at least three consecutive months for more than two successive years, with other causes of cough and sputum having been excluded (6). Chronic bronchitis occurs in approximately $85 \%$ of COPD patients. It is essential to recognize that chronic bronchitis commonly occurs without airway obstruction; a minority of patients with chronic bronchitis have evidence of COPD (7).

AECB
Defining AECB is not simple. Because there are no character-
istic laboratory, radiographic or physiological tests for AECB,
clinical definitions have traditionally been used. Anthonisen
and colleagues (8) proposed three clinical criteria to define
AECB: increased sputum volume, increased sputum purulence
and increased dyspnea over baseline. The most severe, or type I,
exacerbation includes the presence of all three of these symp-
toms. A type II exacerbation exhibits two symptoms. A type III
exacerbation has one symptom plus at least one of the follow-
ing: an upper respiratory tract infection in the previous five
days, increased wheezing, increased cough, fever without an
obvious source, or a 20\% increase in respiratory rate or heart
rate above baseline. Seemungal and colleagues (9) have pro-
posed the use of major and minor criteria to define an exacer-
bation. The major criteria are the three proposed by
Anthonisen et al (8). Minor criteria include wheeze, sore
throat, or symptoms of a common cold such as nasal discharge
or congestion. An exacerbation was defined as the presence of
at least two major symptoms or one major and one minor

${ }^{1}$ University of Toronto, Mount Sinai Hospital, Toronto, Ontario; ${ }^{2}$ Laval University, Hôpital Laval, Ste-Foy, Quebec; ${ }^{3}$ The Toronto Hospital, Toronto Medical Laboratories, Toronto, Ontario; ${ }^{4} \mathrm{McM}$ aster University, Henderson General Hospital, Hamilton, Ontario

Correspondence: Dr Meyer Balter, 640 - 600 University Avenue, Toronto, Ontario M5G 1X5. Telephone 416-586-4663, fax 416-586-4736, e-mailmbalter@mtsinai.on.ca

Reprints: Core Health Services Inc, 1800 Steeles Avenue West - Second Floor, Concord, Ontario L4K 2P3. Telephone 905-760-1991, fax 905-760-0587, e-mail coremail@idirect.com 
symptom for at least two consecutive days. The incidence of AECB varies depending on which definition is used. By applying the Anthonisen et al (8) criteria, the typical patient with COPD averages two to three AECB episodes annually.

\section{ROLE OF BACTERIA IN CHRONIC BRONCHITIS AND AECB}

The normal tracheobronchial tree is sterile. In patients with chronic bronchitis, the lower airways are chronically colonized with bacteria, predominantly Haemophilus influenzae, Moraxella catarrhalis and Streptococcus pneumoniae (10-12). The role that these bacteria play in causing progressive lung disease remains controversial, but a clearer understanding of their interaction with damaged airways is emerging.

Cigarette smoking leads to loss of ciliated epithelium and more viscous airway secretions. The delay in mucociliary clearance allows inhaled bacteria to colonize airways (13). Once bacteria adhere to mucin or epithelial cells in the lower airway, they may further impair mucociliary clearance and may contribute to progressive airway obstruction (Figure 1) $(14,15)$.

Approximately $50 \%$ of exacerbations, particularly those meeting the Anthonisen et al criteria (8), are believed to result from infection, with a minority of these due to viral infection and the remainder due to bacterial infection. Exposure to allergens, pollutants or irritants (cigarette smoke, dust) may also precipitate exacerbations.

Exacerbation rates are an important determinant of diseasespecific health status as measured by a standard quality of life questionnaire (16). Exacerbations may lead to hospitalization, which carries with it a short term mortality rate of $4 \%$ for patients with mild to moderate disease (17), but this rate may be as high as $24 \%$ if patients are admitted to an intensive care unit (ICU) with respiratory failure (18-21). After intensive care, COPD patients have one-year mortality rates of up to 46\% (18-20). Many patients requiring hospitalization for $\mathrm{AECB}$ require subsequent readmissions because of persistent symptoms $(18,21,22)$. In addition, they experience at least a temporary decrease in their functional abilities (23).

\section{DIAGNOSTIC EVALUATION}

Congestive heart failure, pneumonia, pulmonary emboli, pneumothorax, inappropriate oxygen administration and drugs such as tranquilizers may cause worsening of COPD, which must be differentiated from exacerbations. There are no characteristic physical findings in AECB. Fever is uncommon (18) despite statements to the contrary (24), and its presence should suggest a viral infection (25) or underlying pneumonia.

Chest roentgenograms are not helpful in making the diagnosis of AECB, although they should be considered if there is a possibility of pneumonia or congestive heart failure. An exception should be made for patients seen in emergency rooms or admitted to hospital. In these settings, routine chest roentgenograms have been shown to reveal abnormalities that lead to changes in management in $16 \%$ to $21 \%$ of patients (26-28).

Sputum Gram stain and culture have a very limited role in the investigation of the etiology of AECB because, for reasons discussed above, the airways of patients with chronic bronchitis are chronically colonized with bacteria. Sputum analysis should be reserved for patients with frequent exacerbations or chronic

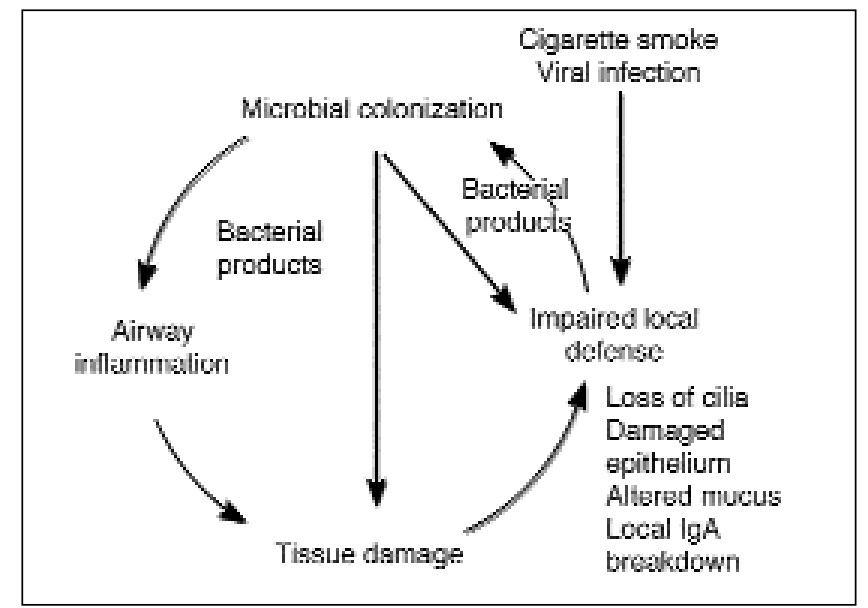

Figure 1) The role of cigarette smoke and viral infection in initializing and perpetuating the 'vicious circle' of impaired local defenses. IgA Immunoglobulin A. Reprinted with permission from reference 134

purulent sputum, in whom the presence of more virulent and/or resistant bacteria is more likely (level III evidence).

Objective measurements of lung function are necessary to confirm the presence of air flow obstruction. Further, in COPD the forced expiratory volume in $1 \mathrm{~s}\left(\mathrm{FEV}_{1}\right)$ is the best predictor of mortality (29) and is important in predicting the need for admission to an ICU (30). Exacerbation frequency is related to the severity of underlying obstruction $(31,32)$, and $\mathrm{FEV}_{1}$ is predictive of clinical outcomes during AECB (33), including benefit from antibiotic therapy (34). There is continued evidence that spirometry is underused in patients at risk for COPD (35-37). However, unless previous lung function values are available, there is little evidence to suggest that spirometry is important in evaluating AECB. Measurement of $\mathrm{FEV}_{1}$ may not be possible in patients with severe AECB. Therefore, it is not necessary for spirometry to be performed during the actual exacerbation (level III evidence). However, an AECB episode is an indication to obtain measurements of pulmonary function after recovery in patients who have not previously had these measurements taken (level III evidence).

\section{MANAGEMENT OF AECB}

Most studies of exacerbation treatment that do not concern antibiotics are focused on exacerbations of COPD, and results may be extrapolated, perhaps inappropriately, to the management of AECB.

Treatment of AECB should provide symptomatic relief, prevent transient loss of pulmonary function and lead to a reevaluation of the disease to reduce the risk of future exacerbations. Patients should be removed from sources of irritants that may worsen lower airway inflammation, including dust, pollutants, and first- and secondhand smoke. Pharmacological therapy aims at decreasing the work of breathing, reducing airway inflammation, reducing the bacterial burden in the lower airways and treating any accompanying hypoxemia.

\section{BRONCHODILATOR THERAPY}

Bronchodilator therapy should be used for the treatment of dyspnea. The majority of the studies examining the role of 
inhaled bronchodilators in patients with exacerbations of COPD have been completed with patients in the emergency room or hospital. It is not clear whether these results are applicable to the much larger population of AECB patients treated at home. Some of the studies comparing anticholinergics with short-acting beta-agonists have combined asthmatic patients with COPD patients. Nonetheless, certain general statements can be made based on the available literature (38).

Most studies comparing short-acting beta-agonists with inhaled anticholinergic agents show no appreciable difference between the two in terms of their effects on pulmonary function (39-42). Some patients clearly benefit from combination bronchodilator therapy, and there does not appear to be a significant increase in side effects with such combinations (level III evidence). Although there has been recent interest in the role of long-acting beta-agonists in the chronic therapy of COPD, these agents have not been studied in AECB and are not recommended for treatment of this condition at the present time.

A meta-analysis of studies in patients with either asthma or COPD that compared the use of metered dose inhalers (MDIs) with nebulized bronchodilators reported no differences in pulmonary function outcomes between delivery systems (43). Therefore, the choice of delivery system should be based on cost and on the patient's ability to use MDIs with a spacer. In most situations, MDIs with an appropriate spacer would be preferred (level II evidence).

There does not appear to be a role for the initiation of therapy with methylxanthines in AECB. The addition of aminophylline to inhaled bronchodilators has not been shown to lead to improved $\mathrm{FEV}_{1}$ but does increase side effects $(44,45)$. For patients who are already on an oral methylxanthine product, it is reasonable to continue the medication during an AECB. However, one must keep in mind possible drug interactions with antibiotics (eg, ciprofloxacin, clarithromycin) and adjust the dose accordingly (level III evidence).

\section{OXYGEN THERAPY}

Patients with chronic bronchitis are at risk of developing hypoxemia during an exacerbation. Low flow oxygen should be administered if hypoxemia is present (46-49). Excess use of oxygen should be avoided, because this may lead to progressive hypercapnia $(50,51)$. The goal of therapy with supplemental oxygen should be to maintain a partial pressure of arterial oxygen at or just above $60 \mathrm{mmHg}$. Decisions regarding the long term need for supplemental oxygen should not be made during an $\mathrm{AECB}$, because up to $50 \%$ of patients requiring oxygen during an exacerbation no longer meet the criteria for home use if reassessed one to three months later (52-54).

\section{MUCUS CLEARING STRATEGIES}

Expectorants or cough suppressants are not effective during AECB. Pharmacological therapy to enhance mucus clearance has not been shown to improve lung function or hasten clinical recovery (55-57), although it may lead to subjective improvement (57). There is no beneficial effect of chest physiotherapy on recovery time from AECB $(58,59)$, and there is some suggestion of worsening pulmonary function and gas exchange with this therapy $(60,61)$. Therefore, we do not endorse the use of mucolytic agents or chest physiotherapy during AECB (level II evidence). Patients should be kept adequately hydrated to prevent excessive mucus viscosity, but increased fluid intake should be avoided, except by patients who are clearly dehydrated (level II evidence).

\section{MISCELLANEOUS THERAPIES}

At this point, there is no evidence supporting the use of leukotriene receptor antagonists in AECB.

The use of noninvasive ventilation in acute exacerbations of COPD has been demonstrated to reduce mortality and decrease the need for intubation and mechanical ventilation $(62,63)$ (level I evidence). Overall, noninvasive ventilation also reduces morbidity and hospital or ICU length of stay (64).

\section{CORTICOSTEROID THERAPY}

Since our first set of guidelines was published in 1994, a number of randomized, placebo-controlled trials have been published confirming the value of oral and/or parenteral corticosteroids in the therapy of AECB (Table 1). These studies demonstrate that systemic steroids lead to a faster improvement in pre- and postbronchodilator $\mathrm{FEV}_{1}$, more rapid recovery of the partial pressure of oxygen, decreased treatment failures and shorter hospitalization rates. The one negative study used only a single dose of methylprednisolone $100 \mathrm{mg}$ in the emergency room, and measured $\mathrm{FEV}_{1}$ outcomes $3 \mathrm{~h}$ and $5 \mathrm{~h}$ after this bolus (65). The follow-up interval was probably not sufficient to detect a significant improvement.

These trials have limitations. All but one (66) were performed in emergency rooms or hospitals, so these results may not be applicable to outpatient populations. Most of the patients had moderate to severe underlying disease. Finally, the dose and duration of corticosteroid therapy varied widely among studies, making it virtually impossible to provide specific treatment recommendations. One must carefully weigh the pros and cons of higher and more prolonged corticosteroid doses in this elderly group of individuals. In the studies quoted, the major side effect in the steroid treatment group was hyperglycemia $(67,68)$.

Systemic steroid therapy may have benefits aside from speeding up recovery from AECB. There is evidence favouring reduced likelihood of relapse (69) and prolongation of the time to the next exacerbation (9).

There is good evidence to support the use of oral or parenteral steroids for most moderately to severely ill patients with AECB (level I evidence). However, further evidence is required before recommending an exact dose and duration for these steroids. It appears that 10 days of therapy is more effective than three days, but no other comparisons have been made (70). We recommend treatment for periods of five to 14 days (level III evidence). Whether patients with mild disease $\left(\mathrm{FEV}_{1} 60 \%\right.$ to $70 \%$ or greater than predicted) also benefit from a course of oral steroids during AECB is unknown at the present time. There are significant negative health consequences with the use of continuous oral corticosteroids in COPD, and similar effects may occur in patients treated with frequent short courses (71).

The role for inhaled steroids in AECB has not yet been defined. Although some studies have failed to demonstrate that inhaled steroids speed up symptom resolution in AECB, these trials were not designed to answer this question (72). A 
TABLE 1

Randomized trials of corticosteroids in chronic obstructive pulmonary disease exacerbations

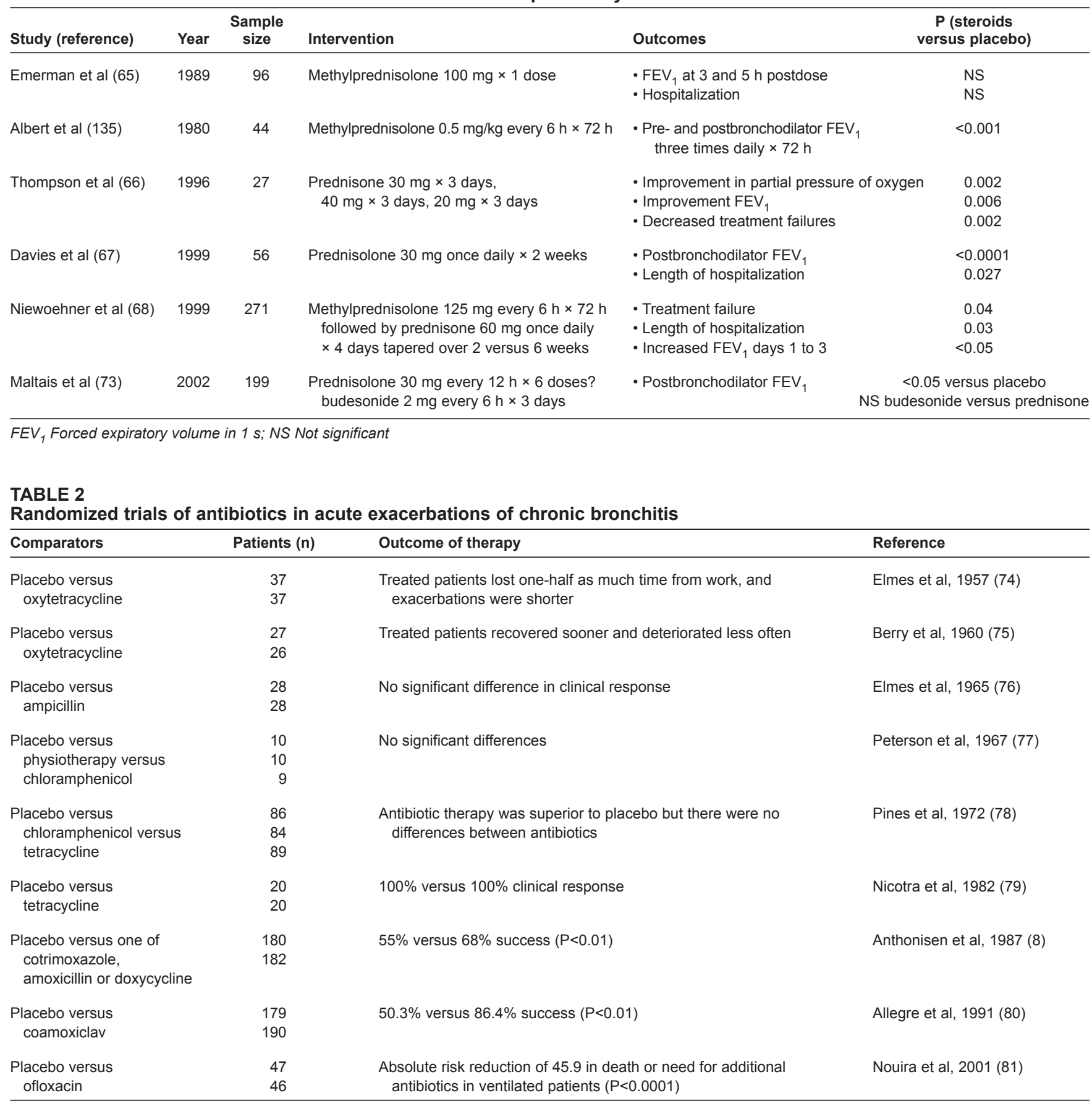

recently published, prospective, randomized trial comparing high dose nebulized budesonide ( 2 mg every $6 \mathrm{~h}$ for $72 \mathrm{~h}$ ) with prednisone ( $30 \mathrm{mg}$ twice daily for $72 \mathrm{~h}$ ) demonstrated no difference between active treatments, with both being superior to placebo in terms of recovery of $\mathrm{FEV}_{1}(73)$.

\section{ANTIBIOTIC THERAPY}

Early, randomized, placebo-controlled antimicrobial trials were inconclusive (Table 2) (74-79), but more recent, well-designed studies have concluded that antibiotics are effective. Anthonisen and coworkers (8), in a landmark study, developed a classification that identified patients that benefited from antimicrobial therapy. Patients who had increased dyspnea, plus increased sputum volume and sputum purulence (type I exacerbation) improved with antibiotics compared with patients receiving placebo. Individuals with only one of the cardinal symptoms (type III exacerbation) did not differ from patients receiving placebo. In another welldesigned trial, Allegre and coworkers (80) demonstrated the superiority of amoxicillin/clavulanate to placebo. A more recent study in 93 mechanically ventilated patients demonstrated that the use of fluoroquinolones compared with placebo was associated with a reduction in mortality, duration of hospital stay and time 
TABLE 3

Risk classification and suggested antimicrobial therapy

\begin{tabular}{|c|c|c|c|c|c|}
\hline Group & Basic clinical state & Symptoms and risk factors & Probable pathogens & First choice & $\begin{array}{l}\text { Alternatives for } \\
\text { treatment failure }\end{array}$ \\
\hline 0 & Acute tracheobronchitis & $\begin{array}{l}\text { Cough and sputum without } \\
\text { previous pulmonary disease }\end{array}$ & Usually viral & $\begin{array}{l}\text { None unless symptoms persist } \\
\text { for longer than } 10 \text { to } 14 \text { days }\end{array}$ & $\begin{array}{l}\text { Macrolide or } \\
\text { tetracycline }\end{array}$ \\
\hline I & $\begin{array}{l}\text { Chronic bronchitis } \\
\text { without risk factors } \\
\text { (simple) }\end{array}$ & $\begin{array}{l}\text { Increased cough and } \\
\text { sputum, sputum purulence } \\
\text { and increased dyspnea }\end{array}$ & $\begin{array}{l}\text { Haemophilus influenzae, } \\
\text { Haemophilus species, } \\
\text { Moraxella catarrhalis, } \\
\text { Streptococcus pneumoniae }\end{array}$ & $\begin{array}{l}\text { Second-generation macrolide, } \\
\text { second- or third-generation } \\
\text { cephalosporin, amoxicillin, } \\
\text { doxycycline, trimethoprim/ } \\
\text { sulfamethoxazole }\end{array}$ & $\begin{array}{l}\text { Fluoroquinolone, } \\
\text { beta-lactam/ } \\
\text { beta-lactamase } \\
\text { inhibitor }\end{array}$ \\
\hline II & $\begin{array}{l}\text { Chronic bronchitis } \\
\text { with risk factors } \\
\text { (complicated) }\end{array}$ & $\begin{array}{l}\text { As in group I plus } \\
\text { (at least one of): } \\
\text { - } \mathrm{FEV}_{1}<50 \% \text { predicted. } \\
\text { - } \geq 4 \text { exacerbations/year } \\
\text { - Cardiac disease } \\
\text { - Use of home oxygen } \\
\text { - Chronic oral steroid use } \\
\text { - Antibiotic use in the } \\
\text { past } 3 \text { months }\end{array}$ & $\begin{array}{l}\text { As in group I, plus: } \\
\text { - Klebsiella species and } \\
\text { other Gram-negative } \\
\text { bacteria } \\
\text { - Increased probability } \\
\text { of beta-lactam resistance }\end{array}$ & $\begin{array}{l}\text { Fluoroquinolone, beta-lactam/ } \\
\text { beta-lactamase inhibitor }\end{array}$ & $\begin{array}{l}\text { May require } \\
\text { parenteral } \\
\text { therapy; consider } \\
\text { referral to a } \\
\text { specialist or } \\
\text { hospital }\end{array}$ \\
\hline III & $\begin{array}{l}\text { Chronic suppurative } \\
\text { bronchitis }\end{array}$ & $\begin{array}{l}\text { - As in group II with constant } \\
\text { purulent sputum } \\
\text { - } \text { Some have bronchiectasis }_{\text {- }} \mathrm{FEV}_{1} \text {, usually } \\
<35 \% \text { predicted } \\
\text { - Multiple risk factors } \\
\text { (eg, frequent exacerbations } \\
\text { and } \mathrm{FEV}_{1}<50 \% \text { ) }\end{array}$ & $\begin{array}{l}\text { As in group II, plus } \\
\text { Pseudomonas aeruginosa } \\
\text { and multiresistant } \\
\text { Enterobacteriaceae family }\end{array}$ & $\begin{array}{l}\text { Ambulatory patients: tailor } \\
\text { treatment to airway pathogen } \\
P \text { aeruginosa common } \\
\text { (ciprofloxacin) } \\
\text { Hospitalized patients: } \\
\text { parenteral therapy usually } \\
\text { required }\end{array}$ & \\
\hline
\end{tabular}

FEV 1 Forced expiratory volume in $1 \mathrm{~s}$

on mechanical ventilation, and a decrease in the need for additional antibiotics (81).

Although the Anthonisen et al (8) classification is helpful in predicting an antimicrobial response, it has only a sensitivity of $59 \%$ and a specificity of $60 \%$ in predicting a bacterial exacerbation (82). While an advance, this would suggest that this particular classification system is only moderately successful in predicting a bacterial etiology and confirming the role of antimicrobials. The presence of green (purulent) secretions in a patient with a history of COPD is $99.4 \%$ sensitive and $77.0 \%$ specific for the yield of high bacterial load and may identify a clear subset of patients likely to benefit from antibiotic therapy (83). In a meta-analysis examining placebo-controlled trials in AECB, antibiotic therapy improved clinical outcomes, and hastened clinical and physiological recovery (84).

Antibiotic resistance and widespread clinical failure in lower respiratory tract infections have not been linked at this time. However, more highly resistant strains have been associated with clinical treatment failures (85) in nosocomial outbreaks. If levels of resistance continue to increase, the value of many classes of antibiotics combinations may diminish. Antibiotic overprescription for nonbacterial infections is a major factor in the emergence of bacterial resistance. We need a risk stratification system that identifies patients not requiring antimicrobial therapy, as well as those requiring more aggressive therapy.

\section{RISK STRATIFICATION}

Failure and relapse rates for AECB in the literature vary from $17 \%$ to $32 \%$ depending on the definition used. Treatment failure can be associated with substantial additional expenditures among patients with significant compromise of lung function who require hospitalization and are at risk for respiratory failure (86). Identification of patients at risk of failing standard antimicrobial therapy with the usual first-line agents may lead to improved outcomes. Patients associated with significant cardiac disease, frequent purulent exacerbations of COPD, generalized debility, malnutrition, chronic corticosteroid administration, use of supplemental oxygen, lengthy duration of COPD, chronic mucous hypersecretion and severe underlying lung function abnormalities tend to fail therapy with usual antimicrobial therapy and have early relapse or hospitalization (16,87-97). Frequent exacerbations, chronic use of oral steroids and poor underlying lung function increase the risk for Klebsiella pneumoniae or Pseudomonas aeruginosa infection (98-100). Frequent courses of antibiotics increase the risk of infection with beta-lactamase-producing bacteria (101). Treatment directed toward resistant pathogens with potent antimicrobial drugs may lead to improved clinical outcomes and overall lower costs if hospital admissions and respiratory failure can be prevented $(102,103)$. Stratification of patients into risk categories may allow the physician to select targeted antimicrobial therapy to prevent some of these consequences.

Our proposed classification system divides patients into four groups (Table 3). This stratification scheme has not been prospectively validated and represents a consensus from our group based on the evidence available (level III evidence).

Group 0 patients have no underlying lung disease and do not have chronic bronchitis, although they may smoke. They present with the acute onset of cough associated with sputum production, often in association with a preceding coryzal illness and 
fever. These patients have acute tracheobronchitis that is usually viral in origin. The presence of purulent sputum in this previously healthy group of patients is not predictive of a bacterial infection. Because there is no underlying lung disease in this group, the illness is usually self limited and runs a benign course. The routine use of antibiotics in patients with uncomplicated acute tracheobronchitis is not justified (104). Giving patients a written leaflet explaining why they do not require an antibiotic has been shown to reduce the use of antibiotics (105). Patients in group 0 may benefit from one to two weeks of inhaled betaagonist bronchodilator therapy to reduce the severity and duration of cough, particularly if wheezing is also present (104).

A small number of these patients have a more protracted course. Mycoplasma pneumoniae and Chlamydia pneumoniae are known etiological agents for acute tracheobronchitis and may be responsible for lack of rapid clinical improvement. Treatment with a macrolide or doxycycline might be considered for patients in whom the cough has not improved after 10 to 14 days (level III evidence). However, there is no good evidence supporting this course.

Group I patients have chronic bronchitis, defined as chronic cough and sputum production for at least three months for two consecutive years, and exacerbations are associated with worsening cough and increased production of purulent sputum. However, they have only mild to moderate impairment of lung function $\left(\mathrm{FEV}_{1}\right.$ greater than $50 \%$ predicted), have less than four exacerbations per year and have no significant cardiac disease. In this group of patients, usual pathogens, including $H$ influenzae, S pneumoniae and $M$ catarrhalis, are present, although viral infection often precedes bacterial superinfection. Treatment with virtually any antibiotic is usually successful and the prognosis is excellent. Until a prospective pharmacoeconomic or clinical study demonstrates some advantage for more potent agents among this group of patients, the recommendation for simple therapy - using agents such as an aminopenicillin, doxycycline or trimethroprim/sulfamethoxazole - is justified. However, most studies showing beneficial results from the use of these agents were performed more than 10 years ago. Given increasing $S$ pneumoniae and $H$ influenzae resistance to these older agents, therapy with selected secondor third-generation cephalosporins, or a second-generation macrolide may be preferable (level III evidence). In the face of treatment failure, alternative therapies such as a betalactam/beta-lactamase inhibitor or fluoroquinolones can be used. However, there are no data demonstrating that these failures are due to resistant organisms.

Group II patients have risk factors for treatment failure such as poor underlying lung function ( $\mathrm{FEV}_{1}$ less than $50 \%$ predicted). Alternatively, they may demonstrate only moderate impairment of lung function ( $\mathrm{FEV}_{1}$ between $50 \%$ and $65 \%$ predicted) but have significant comorbidity (ischemic heart disease or congestive heart failure) and/or experience four or more exacerbations per year. $\mathrm{H}$ influenzae, $\mathrm{S}$ pneumoniae and $\mathrm{M}$ catarrhalis continue to be the predominant organisms, and enteric Gramnegative organisms may be isolated from pulmonary secretions. Treatment with medications directed at resistant organisms, such as a fluoroquinolone or amoxicillin/clavulanic acid should perform better than amoxicillin or other traditional first-line agents.
A number of studies have demonstrated significantly superior bacterial eradication rates with fluoroquinolones compared with cefuroxime or clarithromycin (106-108). There is some evidence suggesting that the enhanced bacterial eradication associated with fluoroquinolones leads to faster symptom resolution and results in more prolonged exacerbation-free intervals compared with cephalosporins and extended spectrum macrolides (level II evidence) (109-112). This preliminary evidence does not warrant fluoroquinolone use in all cases of AECB. There is evidence showing that frequent use of fluoroquinolones leads to the emergence of resistant strains and that COPD patients are a major reservoir for these resistant organisms (113).

It is unclear how group II patients who fail to respond to antimicrobial therapy or who quickly relapse should be treated. It makes sense to treat therapeutic failures or recurrences within three months of antibiotic therapy with another class of antibiotic, but this has never been studied. A significant number of patients with an $\mathrm{FEV}_{1}$ less than $50 \%$ are infected with Pseudomonas species (98-100). Whether this occurs only in the subset of patients with frequent exacerbations remains to be clarified. It is reasonable to get sputum samples, if possible, from these patients with multiple risk factors to help to guide subsequent treatment.

Group III patients suffer from chronic bronchial infection with daily production of purulent secretions. They are subject to frequent exacerbations characterized by increased sputum production, increased sputum purulence, cough and worsening dyspnea, often accompanied by hemoptysis. Some of these patients will have evidence for bronchiectasis on high resolution computed tomography scans. Besides the usual respiratory organisms, other Gram-negative organisms, including Enterobacteriaceae and Pseudomonas species, should be considered as potential pathogens, particularly in patients treated chronically with oral steroids. Ciprofloxacin is the oral agent with the most activity against these species and should be considered the agent of choice when they are identified. As discussed in the previous paragraph, there is some overlap between patients in group II, with multiple risk factors, and patient in group III.

An algorithmic approach to choosing antimicrobial therapy for AECB is summarized in Figure 2.

\section{SUMMARY OF EVIDENCE REGARDING ANTIBIOTIC THERAPY FOR AECB}

1. Antimicrobial therapy is warranted for patients with AECB if they fall into the Anthonisen et al (8) type I or type II categories (level I evidence - two randomized, large scale, double-blind trials and one meta-analysis).

2. Antimicrobial therapy is not warranted for patients with a type III exacerbation (level I evidence).

3. Patients can be stratified according to their risk of treatment failure (level III evidence).

4. A high risk group of patients can be identified on clinical grounds, and the major clinical features are significant impairment of lung function $\left(\mathrm{FEV}_{1} 50 \%\right.$ or less than predicted), frequent exacerbations (four or more per year), lengthy duration of disease, significant comorbidity, use of supplemental oxygen and chronic oral corticosteroid use (level II evidence). 


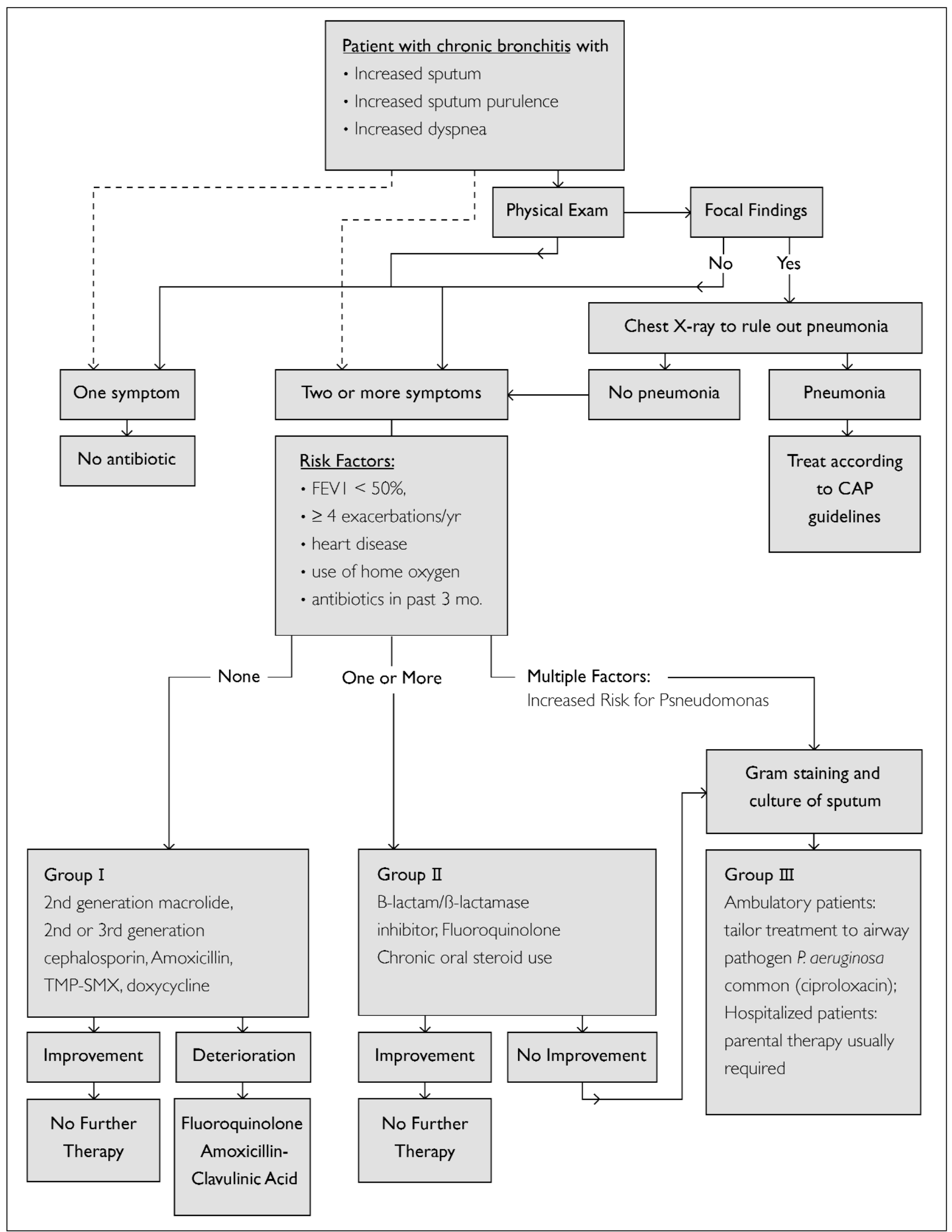

Figure 2) Algorithm for choosing antimicrobial therapy in acute exacerbations of chronic bronchitis. CAP Community-acquired pneumonia; FEV 1 Forced expiratory volume in $1 \mathrm{~s}$; mo. Months; TMP SMX Trimethoprim/sulfamethoxazole 
5. Risk group 0 patients (acute tracheobronchitis) should not be treated with antibiotics unless symptoms persist longer than 10 to 14 days (level I evidence).

6. For risk group 0 patients with persistent symptoms, a macrolide or tetracycline is recommended, because $\mathrm{M}$ pneumoniae, $\mathrm{C}$ pneumoniae or Bordetella pertussis may be pathogens (level III evidence).

7. Although resistant $H$ influenzae and $M$ catarrhalis may be pathogens, traditional 'first-line' agents (aminopenicillins, doxycycline, trimethoprim/sulfamethoxazole) continue to be efficacious and are recommended for patients without risk factors for treatment failure (level II evidence). Second-generation macrolides, and some second- and third-generation cephalosporins (cefuroxime, cefprozil, cefixime) may be better choices given concerns regarding emerging antimicrobial resistance (level III evidence).

8. There are no data to demonstrate that, among group I patients (low risk for treatment failure), there is any clinical or economic benefit derived from using more potent, broader spectrum agents (level I evidence).

9. Broad spectrum, potent agents such as fluoroquinolones or amoxicillin/clavulanate are recommended for group II patients (level III evidence).

10. There is some evidence that fluoroquinolones perform better than other agents in group II patients (level II evidence).

11. Group III patients at risk for $P$ aeruginosa infection (with frequent antimicrobials, structural lung damage and chronic corticosteroids) should be treated with an antipseudomonal agent (ciprofloxacin). Alternative agents currently must be given parenterally (level III evidence).

12. Patients presenting with a relapse or recurrence of $A E C B$ within three months of previous antibiotic therapy should be treated with a different class of antibiotics because of a higher risk of harbouring resistant organisms (level III evidence).

\section{PREVENTION OF AECB}

Cigarette smoking remains the primary risk factor for the development of chronic bronchitis. Smoking cessation has been shown to reduce the rate of decline of $\mathrm{FEV}_{1}$ (114), even in those older than 60 years (115), and also confers a survival advantage (level II evidence) (116). Coughing stops in as many as $77 \%$ of patients who quit smoking and improves in another $17 \%$ of patients. Since patients with chronic cough and sputum production have increased numbers of AECB episodes, it is probable that smoking cessation leads to fewer exacerbations. A recent analysis of patients in the Lung Health Study revealed that recurrent lower respiratory infections hastened the decline in $\mathrm{FEV}_{1}$ in current smokers but not exsmokers (117). A discussion of smoking behavior and the setting of a specific cessation date should be part of every physicianpatient encounter (level III evidence).

Patients with chronic lung disease have a higher risk for complications from influenza infection. Annual influenza vaccination reduces morbidity and mortality from influenza in elderly patients by $50 \%$ and reduces hospitalization for acute and chronic respiratory conditions by as much as 39\% $(118,119)$. Annual influenza vaccination for all patients with chronic bronchitis is strongly recommended (level II evidence). Oral and inhaled neuraminidase inhibitors, which are effective against strains of influenza $\mathrm{A}$ and $\mathrm{B}$, are currently under study for preventing AECB during influenza outbreaks in high risk patients. High risk patients who have not been vaccinated should probably receive prophylaxis during an outbreak (level III evidence).

The value of pneumococcal vaccination in patients with chronic bronchitis is less well established. It is not clear whether vaccination prevents AECB in COPD (120). However, pneumococcal vaccination is safe and can reduce invasive pneumococcal infection, and current recommendations favour vaccinations in all patients with COPD at least once in their lives. In addition, consideration should be given to repeating the vaccine after five to 10 years in high risk patients (level III evidence) (121).

There is no benefit in terms of the rate of decline in lung function in COPD patients treated chronically with inhaled steroids versus those receiving placebo $(31,122-124)$. In addition, patients receiving inhaled steroids had a higher percentage of skin bruising (122), a decrease in bone density of the lumbar spine and femur (124), and a small decrease in mean cortisol concentrations, although this was not associated with any clinical effects (31).

The Inhaled Steroids in Obstructive Lung Disease in Europe study (31) revealed a $25 \%$ reduction in the median exacerbation rate for patients on fluticasone propionate. Another study examining the effects of fluticasone $500 \mu \mathrm{g}$ twice daily versus placebo over the course of six months also showed a significant reduction in both moderate and severe exacerbations in the steroid-treated group (32). Patients with severe impairment in $\mathrm{FEV}_{1}$ and those with frequent exacerbations requiring the use of oral corticosteroids should be considered for therapy with inhaled corticosteroids (level III evidence).

There is little to suggest that there is benefit in regular therapy with oral corticosteroids in patients with COPD. This, combined with the recognition of the significant complications of chronic oral corticosteroid therapy $(125,126)$, including a dose-dependent increase in mortality (127), argues against chronic use of systemic steroids in COPD (level II evidence). It appears that even patients on chronic oral corticosteroids can be weaned off of this medication without any adverse effects on pulmonary function, quality of life or frequency of AECB (128).

There is some preliminary evidence to suggest that COPD patients treated with long-acting beta-agonists or tiotropium, a long-acting anticholinergic agent, have a delayed time to their next exacerbation compared with patients receiving placebo or ipratropium (129-131). Further investigations are necessary before long-acting beta-agonists or long-acting anticholinergics can be recommended for this purpose.

Numerous trials dating back to the mid-1950s have been carried out to determine whether antibiotic prophylaxis reduces the frequency of $\operatorname{AECB}(15,132,133)$. Overall, there is evidence to support antibiotic prophylaxis in patients with frequent exacerbations (level II evidence). However, decisions regarding prophylactic antibiotic treatment should be made on an individual basis.

Please refer to the Canadian Respiratory Journal, Volume 10, Supplement B, for the complete document of Canadian guidelines for the management of acute exacerbations of chronic bronchitis. 
Chronic Bronchitis Working Group: Antonio Anzueto, MD (University of Texas, San Antonio, Texas); Abraham Born, MD, FRCPC (North York General Hospital, University of Toronto, Toronto, Ontario); Jacques Bouchard, MD (St Joseph's Hospital, La Malbaie, Quebec); Nigel JD Duguid, MB, FRCPC (Memorial University, Health Care, Corporation of St John's, St John's, Newfoundland); Godfrey Harding, MD, FACP, FRCPC (University of Manitoba, St Boniface General Hospital, Winnipeg, Manitoba); Marcel Julien, MD, FRCPC (Hopital du Sacre-Coeur, Montreal, Quebec); Noel Lampron, MD (Université Laval, Laval Hospital, Ste-Foy, Quebec); Robert D Levy, MD, FRCPC (University of British Columbia, Vancouver General Hospital, Vancouver, British Columbia); James A McSherry, MB, ChB, FCFP, FRCGP, FRCP Glasg, FAMB (University of Western Ontario, London Health Sciences Centre, London, Ontario); Karl A Weiss, MD, MSc, FRCPC (University of Montreal, Hôpital Maisonneuve-Rosemont, Montreal, Quebec)

ACKNOWLEDGEMENTS: For their contributions and input in reviewing earlier versions of this manuscript, the authors gratefully acknowledge Dr Michael S Niederman (Winthrop University Hospital, Mineola, New York), Dr G Douglas Campbell (LSU Medical Center, Shreveport, Louisiana), Dr Marc Miravitlles (Hospital General Universitarivall d'Hebron, Barcelona, Spain) and Dr Robert Wilson (Royal Brompton Hospital, London, England). We thank Core Health Services Inc for help in the preparation of this manuscript. This summary and its corresponding supplement were sponsored by unrestricted educational grants from Abbott Laboratories Limited, Bayer Inc, Bristol-Myers Squibb Canada Inc, GlaxoSmithKline, JanssenOrtho Inc and Pfizer Canada Inc.

\section{REFERENCES}

1. Balter M, Hyland R, Low D. Recommendations on the management of chronic bronchitis: A practical guide for Canadian physicians. Can Med Assoc J 1994;151(Suppl):7-33.

2. Mandell LA, Marrie TJ, Grossman RF, Chow AW, Hyland RH. Canadian guidelines for the initial management of community-acquired pneumonia: An evidence-based update by the Canadian Infectious Disease Society and the Canadian Thoracic Society. The Canadian Community-Acquired Pneumonia Working Group. Clin Infect Dis 2000;31:383-421.

3. Lung Facts. Ottawa: Canadian Lung Association, 1991.

4. Siafakas NM, Vermeire P, Pride NB, et al. Optimal assessment and management of chronic obstructive pulmonary disease (COPD). The European Respiratory Society Task Force. Eur Respir J 1995;8:1398-420.

5. American Thoracic Society. Standards for the diagnosis and care of patients with chronic obstructive pulmonary disease. Am J Respir Crit Care Med 1995;152:S77-121.

6. Definition and classification of chronic bronchitis for clinical and epidemiological purposes. A report to the Medical Research Council by their Committee on the Aetiology of Chronic Bronchitis. Lancet 1965; i:775-9.

7. Oswald NC, Harold JT, Martin WJ. Clinical pattern of chronic bronchitis. Lancet 1953;2:693-743.

8. Anthonisen NR, Manfreda J, Warren CP, Hershfield ES, Harding GK, Nelson NA. Antibiotic therapy in exacerbations of chronic obstructive pulmonary disease. Ann Intern Med 1987;106:196-204.

9. Seemungal TA, Donaldson GC, Bhowmik A, Jeffries DJ, Wedzicha JA. Time course and recovery of exacerbations in patients with chronic obstructive pulmonary disease. Am J Respir Crit Care Med 2000;161:1608-13.

10. Haas H, Morris J, Samson S, Kilbourn J, Kim P. Bacterial flora of the respiratory tract in chronic bronchitis: Comparison of transtracheal, fiberbronchoscopic, and oropharyngeal sampling methods. Am Rev Respir Dis 1977;116:41-7.

11. Hager H, Verghese A, Alvarez S, Berk S. Branhamella catarrhalis respiratory infections. Rev Infect Dis 1987;9:1140-9.

12. Tager I, Speizer F. Role of infection in chronic bronchitis. N Engl J Med 1975;292:563-71.
13. Vishwanath S, Ramphal R. Adherence of Pseudomonas aeruginosa to human tracheobronchial mucin. Infect Immun 1984:45:197-202.

14. Cole P, Wilson R. Host-microbial interrelationships in respiratory infection. Chest 1989;95:217S-21S.

15. Murphy T, Sethi S. Bacterial infection in chronic obstructive pulmonary disease. Am Respir Dis 1992;146:1067-83.

16. Seemungal TA, Donaldson GC, Paul EA, Bestall JC, Jeffries DJ, Wedzicha JA. Effect of exacerbation on quality of life in patients with chronic obstructive pulmonary disease. Am J Respir Crit Care Med 1998; 157:1418-22.

17. Mushlin AI, Black ER, Connolly CA, Buonaccorso KM, Eberly SW. The necessary length of hospital stay for chronic pulmonary disease. JAMA 1991;266:80-3.

18. Connors AF, Dawson NV, Thomas C, et al. Outcomes following acute exacerbation of severe chronic obstructive lung disease. The SUPPORT investigators (Study to Understand Prognoses and Preferences for Outcomes and Risks of Treatments). Am J Respir Crit Care Med 1996;154:959-67.

19. Burk RH, George RB. Acute respiratory failure in chronic obstructive pulmonary disease. Immediate and long-term prognosis. Arch Intern Med 1973;132:865-8.

20. Seneff MG, Wagner DP, Wagner RP, Zimmerman JE, Knaus WA Hospital and 1-year survival of patients admitted to intensive care units with acute exacerbation of chronic obstructive pulmonary disease. JAMA 1995;274:1852-7.

21. Cydulka RK, McFadden ER Jr, Emerman CL, Sivinski LD, Pisanelli W, Rimm AA. Patterns of hospitalization in elderly patients with asthma and chronic obstructive pulmonary disease. Am J Respir Crit Care Med 1997;156:1807-12.

22. Osman IM, Godden DJ, Friend JA, Legge JS, Douglas JG. Quality of life and hospital re-admission in patients with chronic obstructive pulmonary disease. Thorax 1997;52:67-71.

23. Peach H, Pathy MS. Follow-up study of disability among elderly patients discharged from hospital with exacerbations of chronic bronchitis. Thorax 1981;36:585-9.

24. Hagedorn SD. Acute exacerbations of COPD. How to evaluate severity and treat the underlying cause. Postgrad Med 1992;91:105-7.

25. Seemungal T, Harper-Owen R, Bhowmik A, et al. Respiratory viruses, symptoms, and inflammatory markers in acute exacerbations and stable chronic obstructive pulmonary disease. Am J Respir Crit Care Med 2001;164:1618-23.

26. Sherman S, Skoney JA, Ravikrishnan KP. Routine chest radiographs in exacerbations of chronic obstructive pulmonary disease. Diagnostic value. Arch Intern Med 1989;149:2493-6.

27. Wolkove N, Dajczman E, Colacone A, Kreisman H. The relationship between pulmonary function and dyspnea in obstructive lung disease. Chest 1989;96:1247-51.

28. Peto R, Speizer F, Cochrane A, et al. The relevance in adults of air-flow obstruction but not of mucus hypersecretion, to mortality from chronic lung disease. Results from 20 years of prospective observation. Am Rev Respir Dis 1983;128:491-500.

29. Hodgkin JE. Prognosis in chronic obstructive pulmonary disease. Clin Chest Med 1990;11:555-69.

30. Vitacca M, Clini E, Porta R, Foglio K, Ambrosino N. Acute exacerbations in patients with COPD: Predictors of need for mechanical ventilation. Eur Respir J 1996;9:1487-93.

31. Burge PS, Calverley PM, Jones PW, Spencer S, Anderson JA, Maslen TK. Randomised, double blind, placebo controlled study of fluticasone propionate in patients with moderate to severe chronic obstructive pulmonary disease: The ISOLDE trial. Br Med J 2000;320:1297-303.

32. Paggiaro PL, Dahle R, Bakran I, Frith L, Hollingworth K, Efthimiou J. Multicentre randomised placebo-controlled trial of inhaled fluticasone propionate in patients with chronic obstructive pulmonary disease. International COPD Study Group. Lancet 1998;351:773-80.

33. Niewoehner D, Collins D, Erbland M. Relation to FEV $\mathrm{F}_{1}$ to clinical outcomes during exacerbations of chronic obstuctive pulmonary disease. The Department of Veterans Affairs Cooperative Study Group. Am J Respir Crit Care Med 2000;161:1201-5.

34. Allegra L, Blasi F, deBernardi B, Cosentini R, Tarsia P. Antibiotic treatment and baseline severity of disease in acute exacerbations of chronic bronchitis: A re-evaluation of previously published data of a placebo controlled randomized study. Pulm Pharmacol Ther 2001;14:149-55.

35. Mannino DM, Etzel RA, Flanders WD. Do the medical history and physical examination predict low lung function? Arch Intern Med 1993;153:1892-7.

36. Kesten S, Chapman K. Physician perceptions and management of COPD. Chest 1993;104:254-8.

37. Renwick DS, Connolly MJ. Prevalence and treatment of chronic airways obstruction in adults over the age of 45. Thorax 1996;51:164-8. 
38. Kuhl DA, Agiri OA, Mauro LS. Beta-agonists in the treatment of acute exacerbation of chronic obstructive pulmonary disease. Ann Pharmacother 1994;28:1379-88.

39. Emerman CL, Cydulka RK. Effect of different albuterol dosing regimens in the treatment of acute exacerbation of chronic obstructive pulmonary disease. Ann Emerg Med 1997;29:474-8.

40. O'Driscoll BR, Taylor RJ, Horsley MG, Chambers DK, Bernstein A. Nebulised salbutamol with and without ipratropium bromide in acute airflow obstruction. Lancet 1989;i:1418-20.

41. Backman R, Helstrom P. Fenoterol and ipratropium bromide for treatment of patients with chronic bronchitis. Curr Ther Res 1985;38:135-40.

42. Karpel JP, Pesin J, Greenberg D, Gentry E. A comparison of the effects of ipratropium bromide and metaproterenol sulfate in acute exacerbations of COPD. Chest 1990;98:835-9.

43. Turner M, Patel A, Ginsburg S, FitzGerald J. Bronchodilator delivery in acute airflow obstruction. A meta-analysis. Arch Intern Med 1997; 157:1736-44.

44. Rice KL, Leatherman JW, Duane PG, et al. Aminophylline for acute exacerbations of chronic obstructive pulmonary disease. A controlled trial. Ann Intern Med 1987;107:305-9.

45. Seidenfeld JJ, Jones WN, Moss RE, Tremper J. Intravenous aminophylline in the treatment of acute bronchospastic exacerbations of chronic obstructive pulmonary disease. Ann Emerg Med 1984;13:248-52.

46. Schmidt GA, Hall JB. Acute or chronic respiratory failure. Assessment and management of patients with COPD in the emergency setting. JAMA 1989;261:3444-53.

47. Bone R, Pierce A, Johnson RJ. Controlled oxygen administration in acute respiratory failure in chronic obstructive pulmonary disease: A reappraisal. Am J Med 1978;65:896-902.

48. Rosen RL. Acute respiratory failure and chronic obstructive lung disease. Med Clin North Am 1986;70:895-907.

49. Derenne JP, Fleury B, Pariente R. Acute respiratory failure of chronic obstructive pulmonary disease. Am Rev Respir Dis 1988;138:1006-33.

50. Weinberger SE, Schwartzstein RM, Weiss JW. Hypercapnia. N Engl J Med 1989;321:1223-31.

51. Stradling JR. Hypercapnia during oxygen therapy in airways obstruction: A reappraisal. Thorax 1986;41:897-902.

52. Levi-Valensi P, Weitzenblum E, Pedinielli JL, Racineux JL, Duwoos H. Three-month follow-up of arterial blood gas determinations in candidates for long-term oxygen therapy. A multicentric study. Am Rev Respir Dis $1986 ; 133: 547-51$.

53. European Society of Pneumology Task Group. Recommendations for long term oxygen therapy (LTOT). Eur Respir J 1992;2:160-4.

54. Timms RM, Kvale PA, Anthonisen NR, et al. Selection of patients with chronic obstructive pulmonary disease for long-term oxygen therapy. JAMA 1981;245:2514-5.

55. Finiguerra M, Conti P, Figura I, Legnani W, Morandini G. Clinical study on an antibiotic and mucolytic association (amoxicillin and domiodal) in gypersecretory chronic bronchopulmonary diseases. Curr Ther Res 1982;31:895-905.

56. Langlands JH. Double-blind clinical trial of bromhexine as a mucolytic drug in chronic bronchitis. Lancet 1970;i:448-50.

57. Aylward M. A between-patient, double-blind comparison of S-carboxymethylcysteine and bromhexine in chronic obstructive bronchitis. Curr Med Res Opin 1973;1:219-27.

58. Anthonisen P, Riis P, Sogaard-Anderson T. The value of lung physiotheraphy in the treatment of acute exacerbations in chronic bronchitis. Acta Med Scand 1964;175:715-9.

59. Newton DA, Bevans HG. Physiotherapy and intermittent positivepressure ventilation of chronic bronchitis. BMJ 1978;ii:1525-8.

60. Campbell AH, O'Connell JM, Wilson F. The effect of chest physiotherapy upon the $\mathrm{FEV}_{1}$ in chronic bronchitis. Med J Aust $1975 ; 1: 33-5$

61. Connors AF, Hammon WE, Martin RJ, Rogers RM. Chest physical therapy. The immediate effect on oxygenation in acutely ill patients. Chest 1980;78:559-64

62. Plant PK, Owen JL, Elliott MW. Early use of non-invasive ventilation for acute exacerbations of chronic obstructive pulmonary disease on general respiratory wards: A multicentre randomised controlled trial. Lancet 2000;355:1931-5.

63. Keenan SP, Kernerman PD, Cook DJ, Martin CM, McCormack D, Sibbald WJ. Effect of noninvasive positive pressure ventilation on mortality in patients admitted with acute respiratory failure: A meta-analysis. Crit Care Med 1997;25:1685-92.

64. Mehta S, Hill NS. Noninvasive ventilation. Am J Respir Crit Care Med 2001;163:540-77.

65. Emerman C, Connors A, Lukens T, May M, Effron D. A randomized controlled trial of methylprednisolone in the emergency treatment of acute exacerbations of COPD. Chest 1989;95:563-7.
66. Thompson W, Nielson C, Carvalho P, Charan N, Crowley J. Controlled trial of oral prednisone in outpatients with acute COPD exacerbation. Am J Respir Crit Care Med 1996;154:407-12.

67. Davies L, Angus R, Calverley P. Oral corticosteroids in patients admitted to hospital with exacerbations of chronic obstructive pulmonary disease: A prospective randomised controlled trial. Lancet 1999;354:456-60.

68. Niewoehner D, Erbland M, Deupree R, et al. Effect of systemic glucocorticoids on exacerbations of chronic obstructive pulmonary disease. Department of Veterans Affairs Cooperative Study Group. N Engl J Med 1999;340:1941-7.

69. Murata G, Gorby M, Chick T, Halperin A. Intravenous and oral corticosteroids for the prevention of relapse after treatment for decompensated COPD: Effect on patients with a history of multiple relapses. Chest 1990;98:845-9.

70. Sayiner A, Aytemur ZA, Cirit M, Unsal I. Systemic glucocorticoids in severe exacerbations of COPD. Chest 2001;119:726-30.

71. Decramer M, Gosselink R, Troosters T, Verschueren M, Evers G. Muscle weakness is related to utilization of health care resources in COPD. Eur Respir J 1997;10:417-23.

72. Woolhouse C, Hill S, Stockley R. Symptom resolution assessed using a patient directed diary card during treatment of acute exacerbations of chronic bronchitis. Thorax 2001;56:947-53.

73. Maltais F, Ostinelli J, Bourbeau J, Tonnel A, Jacquemet N, Haddon J. Comparison of nebulized budesonide and oral prednisolone with placebo in the treatment of acute exacerbations of chronic obstructive pulmonary disease: A randomized controlled trial. Am J Respir Crit Care Med 2002;165:698-703.

74. Elmes P, Fletcher C, Dutton A. Prophylactic use of oxytetracycline for exacerbations of chronic bronchitis. Br Med J 1957;ii:1272-5.

75. Berry D, Fry J, Hindley C, et al. Exacerbations of chronic bronchitis treatment with oxytetracycline. Lancet 1960;i:137-9.

76. Elmes P, King T, Langlands J, et al. Value of ampicillin in the hospital treatment of exacerbations of chronic bronchitis. Br Med J 1965;5467:904-8.

77. Peterson E, Esmann V, Honcke P, Munkner C. A controlled study of the effect of treatment on chronic bronchitis: An evaluation using pulmonary function tests. Acta Med Scand 1967;182:293-305.

78. Pines A, Raafat H, Greenfield J, Linsell W, Solari M. Antibiotic regimens in moderately ill patients with purulent exacerbations of chronic bronchitis. Br J Dis Chest 1972;66:107-15.

79. Nicotra MB, Rivera M, Awe RJ. Antibiotic therapy of acute exacerbations of chronic bronchitis. A controlled study using tetracycline. Ann Intern Med 1982;97:18-21.

80. Allegre L, Grasi E, Pozzi E. Puolo degli antibiotici nel trattamento delle riacutizza della bronchite cronica. Ital J Chest Dis 1991;45:138-48.

81. Nouira S, Marghli S, Belghith M, Besbes L, Elatrous S, Abroug F. Once daily oral ofloxacin in chronic obstructive pulmonary disease exacerbation requiring mechanical ventilation: A randomized placebo-controlled trial. Lancet 2001;358:2020-35.

82. Sethi S, Paluri R, Grant E, Murphy T. Prediction models for the etiology of acute exacerbations of COPD. Am J Respir Crit Care Med 1999;159:A819. (Abst)

83. Stockley R, O'Brien C, Pye A, Hill S. Relationship of sputum color to nature and outpatient management of acute exacerbations of COPD. Chest 2000;117:1638-45.

84. Saint S, Bent S, Vittinghoff E, Grady D. Antibiotics in chronic obstructive pulmonary disease exacerbations. A meta-analysis. JAMA 1995;273:957-60.

85. Weiss K, Restieri C, Gauthier R, et al. A nosocomial outbreak of fluoroquinolone-resistant Streptococcus pneumoniae. Clin Infect Dis 2001;33:517-22.

86. Macfarlane JT, Colville A, Guion A, Macfarlane RM, Rose DH. Prospective study of aetiology and outcome of adult lower-respiratory-tract infections in the community. Lancet 1993;341:511-4.

87. Vestbo J, Prescott E, Lange P. Association of chronic mucus hypersecretion with $\mathrm{FEV}_{1}$ decline and chronic obstructive pulmonary disease morbidity. Copenhagen City Heart Study Group. Am J Respir Crit Care Med 1996;153:1530-5.

88. Ball P, Harris J, Lowson D, Tillotson G, Wilson R. Acute infective exacerbations of chronic bronchitis. QJM 1995;88:61-8.

89. Dewan NA, Rafique S, Kanwar B, et al. Acute exacerbations of COPD: Factors associated with poor treatment outcome. Chest 2000;117:662-71.

90. Miravitlles M, Murio C, Guerrero T, on behalf of the DAFNE study group. Factors associated with relapse after ambulatory treatment of acute exacerbations of chronic bronchitis. Eur Respir J 2001;17:928-33.

91. Adams S, Melo J, Luther M, Anzueto A. Antibiotics are associated with lover relapse rates in outpatients with acute exacerbations of COPD. Chest 2000;117:1345-52.

92. Grossman R, Mukherjee J, Vaughan D, et al. A 1-year community-based health economic study of ciprofloxacin vs usual antibiotic treatment in 
acute exacerbations of chronic bronchitis. The Canadian Ciprofloxacin Health Economic Study Group. Chest 1998;113:131-41.

93. Kessler R, Faller M, Fourgaut G, Nennevier B, Weitsenblum E. Predictive factors of hospitalization for acute exacerbation in a series of 64 patients with chronic obstructive pulmonary disease. Am J Crit Care Med 1999;159:158-64.

94. Garcia-Aymerich J, Monso E, Marrales R, et al. Risk factors for a chronic obstructive pulmonary disease exacerbation. Am J Respir Crit Care Med 2001;164:1002-7.

95. Miravitlles M, Guerrero T, Mayordomo C, Sanchez-Agudo L, Nicolau F, Segu JL. Factors associated with increased risk of exacerbation and hospital admission in a cohort of ambulatory COPD patients: A multiple logistic regression analysis. The EOLO Study Group. Respiration 2000;67:495-501.

96. Low DE, de Azavedo J, Weiss K, et al. Antimicrobial resistance among clinical isolates of Streptococcus pneumoniae in Canada during 2000. Antimicrob Agents Chemother 2002;46:1295-301.

97. Ball P. Epidemiology and treatment of chronic bronchitis and its exacerbations. Chest 1995;108(Suppl 2):43S-52S.

98. Eller J, Ede A, Schaberg T, Niederman MS, Mauch H, Lode H. Infective exacerbations of chronic bronchitis: Relation between bacteriologic etiology and lung function. Chest 1998;113:1542-8.

99. Miravitlles M, Espinosa C, Fernandez-Laso E, Martos JA, Maldonado JA, Gallego M. Relationship between bacterial flora in sputum and functional impairment in patients with acute exacerbations of COPD. Study Group of Bacterial Infection in COPD. Chest 1999;116:40-6.

100. Soler N, Torres A, Ewig S, et al. Bronchial microbial patterns in severe exacerbations of chronic obstructive pulmonary disease. Am J Respir Crit Care Med 1998;157:1498-505.

101. Sportel JH, Koeter GH, van Altena R, Lowenberg A, Boersma WG. Relation between beta-lactamase producing bacteria and patient characteristics in chronic obstructive pulmonary disease (COPD). Thorax 1995;50:249-53.

102. Niederman MS, McCombs JS, Unger AN, Kumar A, Popovian R. Treatment cost of acute exacerbations of chronic bronchitis. Clin Ther 1999;21:576-91.

103. Miravitlles M, Murio C, Guerrero T, Gisbert R. Pharmacoeconomic evaluation of acute exacerbations of chronic bronchitis and COPD. Chest 2002;121:1449-55.

104. Gonzales R, Sande M. Uncomplicated acute bronchitis. Ann Intern Med 2000;133:981-91.

105. Macfarlane J, Holmes W, Gard P, Thornhill D, Macfarlane R, Hubbard R. Reducing antibiotic use for acute bronchitis in primary care: Blinded, randomised conrolled trial of patient information leaflet. BMJ 2002;324:91-4.

106. Wilson R, Kubin I, Deppermann K-M, et al. Five day moxifloxacin therapy compared with 7 day clarithromycin therapy for the treatment of acute exacerbations of chronic bronchitis. J Antimicrob Chemother 1999;44:501-13.

107. Shah PM, Maesen FPV, Dolmann A, Vetter N, Fiss E, Wesch R. Levofloxacin versus cefuroxime axetil in the treatment of acute exacerbations of chronic bronchitis: Results of a randomized, double-blind study. J Antimicrob Chemother 1999;43:529-39.

108. Langan C, Zuck P, Vogel F, et al. Randomized, double-blind study of short-course ( 5 day) grepafloxacin versus 10 day clarithromycin in patients with acute bacterial exacerbations of chronic bronchitis. J Antimicrob Chemother 1999;44:515-23.

109. Chodosh S. Treatment of acute exacerbations of chronic bronchitis: State of the art. Am J Med 1991;91(Suppl 6A):87S-92S.

110. Chodosh S, Schreurs A, Siami G, et al. Efficacy of oral ciprofloxacin vs. clarithromycin for treatment of acute bacterial exacerbations of chronic bronchitis. The Bronchitis Study Group. Clin Infect Dis 1998;27:730-8.

111. Wilson R, Schentag J, Ball P, Mandell L, 068 Study Group. A comparison of gemifloxacin and clarithromycin in acute exacerbations of chronic bronchitis and long-term clinical outcomes. Clin Ther 2002;24:639-52.

112. Wilson R, Jones P, Schaberg T, et al. A clinical and outcomes assessment of the management of acute exacerbations of chronic bronchitis (AECB): The Mosaic Study. Twelfth European Respiratory Society Annual Congress, Stockholm, Sweden, September 14 to 18, 2002.
113. Ho P, Tse W, Tsang K, Ng T, Cheng V, Chan R. Risk factors for acquisition of levofloxacin-resistant Streptococcus pneumoniae: A case-control study. Clin Infect Dis 2001;32:701-7.

114. Anthonisen N, Connett J, Kiley J, et al. Effects of smoking intervention and the use of an inhaled anticholinergic bronchodilator on the rate of

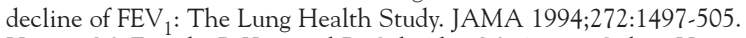

115. Higgins M, Enright P, Kronmal R, Schenker M, Anton-Culver H, Lyles M. Smoking and lung function in elderly men and women. The Cardiovascular Health Study. JAMA 1993;269:2741-8.

116. Postma D, Sluiter H. Prognosis of chronic obstructive pulmonary disease: The Dutch experience. Am Rev Respir Dis 1989;140:S100-5.

117. Kanner RE, Anthonisen NR, Connett JE, for the Lung Health Study Research Group. Lower respiratory illnesses promote $\mathrm{FEV}_{1}$ decline in current smokers but not ex-smokers with mild chronic obstructive pulmonary disease: Results from the Lung Health Study. Am J Respir Crit Care Med 2001;164:358-64.

118. Nichol K, Margolis K, Wuorenma J, Von Sternberg T. The efficacy and cost effectiveness of vaccination against influenza among elderly persons living in the community. N Engl J Med 1994;331:778-84.

119. Nichol K, Baken L, Nelson A. Relation between influenza vaccination and outpatient visits, hospitalizations and mortality among elderly patients with chronic lung disease. Ann Intern Med 1999;130:397-403.

120. Butler J, Breiman R, Campbell J, Lipman H, Broome C, Facklam R. Pneomococcal polysaccharide vaccine efficacy: An evaluation of current recommendations. JAMA 1993;270:1826-31.

121. Centre for Disease Control and Prevention. Prevention of pneumococcal disease. MMWR Morb Mortal Wkly Rep 1997;46:1-24.

122. Pauwels RA, Lofdahl CG, Laitinen LA, et al. Long-term treatment with inhaled budesonide in persons with mild chronic obstructive pulmonary disease who continue smoking. European Respiratory Society Study on Chronic Obstructive Pulmonary Disease. N Engl J Med 1999;340:1948-53.

123. Vestbo J, Sorensen T, Lange P, Brix A, Torre P, Viskum K. Long-term effect of inhaled budesonide in mild and moderate chronic obstructive pulmonary disease: A randomised controlled trial. Lancet 1999;353:1819-23.

124. The Lung Health Study Research Group. Effect of inhaled triamcinolone on the decline in pulmonary function in chronic obstructive pulmonary disease. N Engl J Med 2000;343:1902-9.

125. McEvoy CE, Niewoehner DE. Adverse effects of corticosteroid therapy for COPD. A critical review. Chest 1997;111:732-43.

126. McEvoy CE, Ensrud KE, Bender E, et al. Association between corticosteroid use and vertebral fractures in older men with chronic obstructive pulmonary disease. Am J Respir Crit Care Med 1998;157:704-9.

127. Schols A, Wesseling G, Kester A, et al. Dose dependent increased mortality risk in COPD patients treated with oral glucocorticoids. Eur Respir J 2001;17:337-42.

128. Rice KL, Rubins JB, Lebahn F, et al. Withdrawal of chronic systemic corticosteroids in patients with COPD: A randomized trial. Am J Respir Crit Care Med 2000;162:174-8.

129. Mahler DA, Donohue JF, Barbee RA, et al. Efficacy of salmeterol xinafoate in the treatment of COPD. Chest 1999;115:957-65.

130. Vincken W, van Noord J, Greefhorst A, et al. Improved health outcomes in patients with COPD during 1 yr's treatment with tiotropium. Eur Respir J 2002;19:209-16.

131. Casaburi R, Mahler D, Jones P, Wanner A, San Pedro G, ZuWallack R. A long-term evaulation of once-daily inhaled tiotropium in chronic obstructive pulmonary disease. Eur Respir J 2002;19:217-24.

132. Ruben F. Prophylactic treatment of chronic bronchitis. Semin Respir Infect 1988;3:72-80.

133. Liippo K, Pelliniemi T-T, Lehto H. Trimethoprim prophylaxis of acute exacerbations in chronic obstructive pulmonary disease. Acta Med Scand 1987;21:455-9.

134. Balter MS, Hyland RH, Low D, et al. Recommendations on the management of chronic bronchitis: A practical guide for Canadian physicians. Can Med Assoc J 1994;151(Suppl 10):S7-23.

135. Albert R, Martin T, Lewis S. Controlled clinical trial of methylprednisolone in patients with chronic bronchitis and acute respiratory insufficiency. Ann Intern Med 1980;92:753-8. 


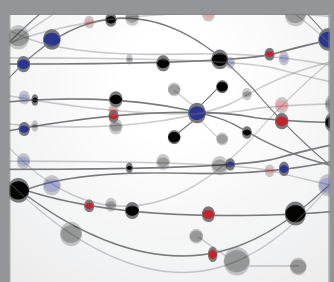

The Scientific World Journal
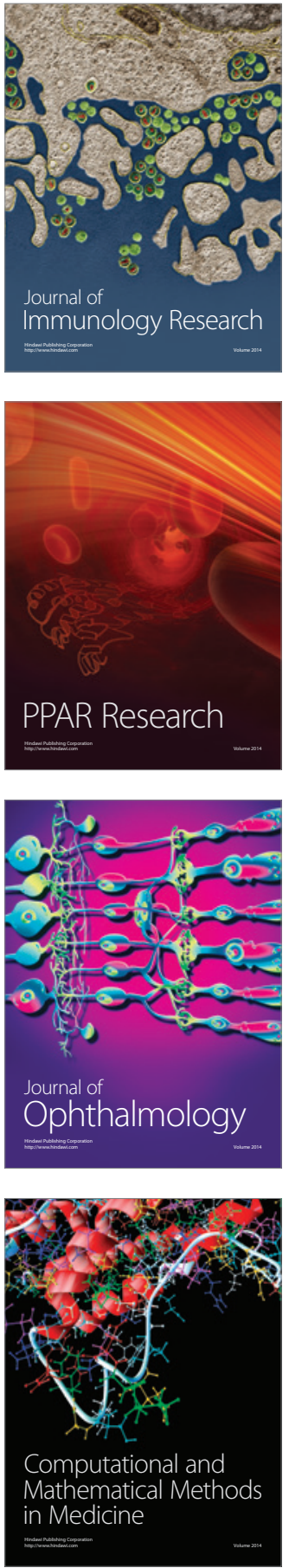

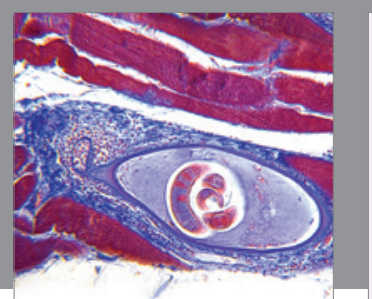

Gastroenterology Research and Practice

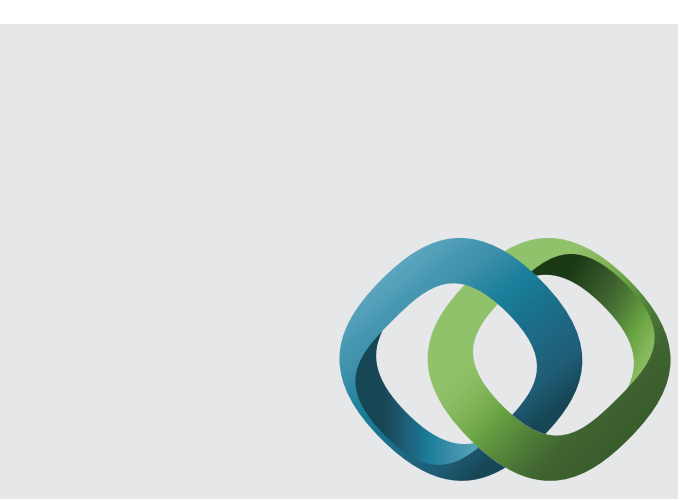

\section{Hindawi}

Submit your manuscripts at

http://www.hindawi.com
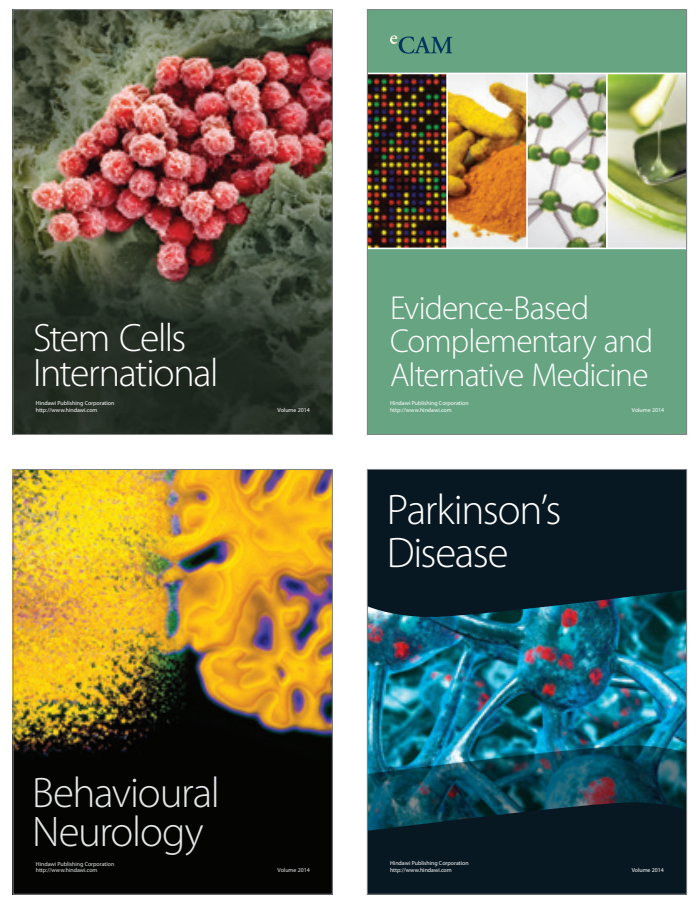
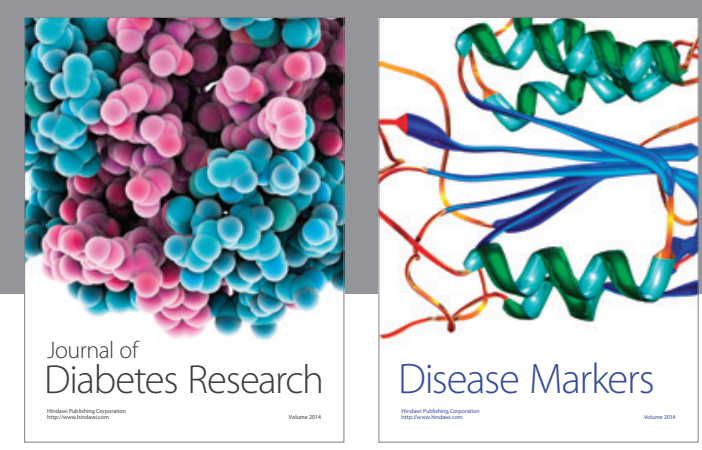

Disease Markers
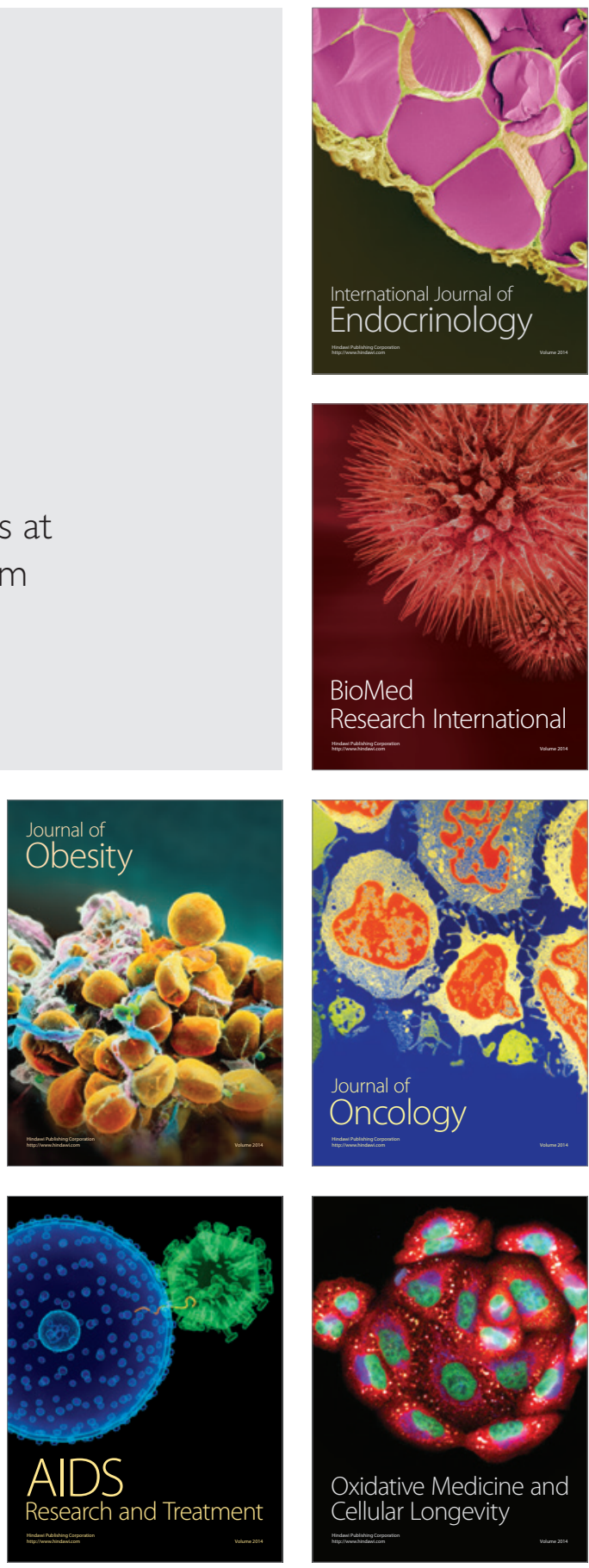